\title{
Carbonate blocks found in muddy sediment off Cape Breton Island, Nova Scotia: pieces of small authigenic carbonate mounds and vents related to hydrocarbon seeps?
}

\author{
Peter Wallace*, Matt Harrington, and Ryan Cook \\ Earth Sciences Department, Dalhousie University, Halifax, Nova Scotia B3H 4R2, Canada \\ * corresponding author: <peter.wallace@dal.ca>
}

Date received: 27 January 2006 Date accepted: 7 August 2006

\begin{abstract}
Carbonate blocks brought up from the seafloor during drag fishing in a small restricted area offshore northern Cape Breton Island are irregularly shaped and range in size from $6 \mathrm{~cm}^{3}$ to $>1 \mathrm{~m}^{3}$. They have smooth to "clinkery", dendritic, or "popcorn-surface" structures, can be layered to massive, and are porous. Many are highly porous and/or eroded. They contain fine-grained siliciclastic material (mud to granule sized) with minor amounts of bioclasts cemented by calcite. Three blocks have vent structures and some have pores lined by fine-grained sparite. Seismic lines in the vicinity of the discovery area show acoustic turbidity, bright spots interpreted to be hydrocarbon seeps, diaper-like structures, and columnar sediment disturbances that reach to bedrock. Outside the immediate area, pock marks occur on the sediment surface. Carbon isotope values from shelly material cemented in the blocks range from $\delta^{13} \mathrm{C}=-9.41$ to -35.27 $\%$ PDB (Pee Dee Belemnite) with an algae encrustation or bacterial mat yielding - 61.38 \%o PDB. From the isotopic analysis and the seismic interpretation we are confident that these blocks are pieces of carbonate mounds and vents formed by methanogenesis of hydrocarbon from slow seeps on the seafloor, the hydrocarbon originating either within the recent sediment and/or from bedrock, most likely the latter. The ecology of these mounds has not been studied and needs further work in this area of active commercial fishing.
\end{abstract}

\section{RÉSUMÉ}

Les blocs de roches carbonatées repêchées du fond de la mer par des chalutiers dans un petit secteur à accès restreint au large, au nord de l'île du Cap-Breton, sont d'apparence irrégulière et leur taille varie entre $6 \mathrm{~cm}^{3}$ et plus de $1 \mathrm{~m}^{3}$. Ils sont de texture lisse à « scoriacée », sont de nature dendritique et présentent une surface de « maïs éclaté »; les blocs peuvent être stratifiés ou d'apparence massive, et ils sont poreux. Un bon nombre des blocs sont très poreux ou érodés, ou les deux. Ils contiennent du matériau silicoclastique à grain fin (entre la boue et les granules), ainsi que de petites quantités de bioclastes à cimentation calcitique. Trois blocs présentent une structure à orifices, tandis que d'autres ont des pores recouverts de sparite à grain fin. Le profil sismique dans les environs de la découverte indiquent une turbidité acoustique, et présentent des zones claires dont l'interprétation donne à penser qu'il s'agit de suintements d'hydrocarbures, à structure stratiforme, ainsi que des perturbations de sédiments prismatiques qui atteignent le substratum rocheux. À une certaine distance de la découverte, on note des marques de rigoles sur la surface sédimentaire. Les valeurs des isotopes de carbone tirées des matières coquillières cimentées dans les blocs varient entre $\delta^{13} \mathrm{C}=-9.41$ et $-35.27 \%$ PDB (bélemnites de la formation Pee Dee), et s'accompagnent d'une incrustation algale ou d'une matte bactérienne d'une valeur de -61.38 \% PDB. À la lumière de l'analyse isotopique et de l'interprétation sismique, nous sommes relativement certains d'être ici en présence de sections de monticules et d'orifices carbonatés créés par la méthanogénèse d'hydrocarbures, à partir de suintements lents du fond de la mer, les hydrocarbures provenant soit des sédiments récents eux-mêmes, soit du substratum rocheux, cette deuxième explication étant vraisemblablement la plus plausible. L'écologie de ces monticules n'a fait l'objet d'aucune étude, et il faudrait réaliser d'autres travaux dans cette zone où la pêche commerciale est pratiquée.

[Traduit par la rédaction] 


\section{INTRODUCTION}

In the Fall of 2001, members of the Ecology Action Centre, Marine Affairs Committee, brought a calcareous rock specimen dragged from the sea floor off Cape Breton Island to the attention of the senior author. Fishermen had heard about the deep water corals being studied offshore Nova Scotia and were curious if these rocks were related to them and what it might mean to their fishery. In the ensuing years two honours students and the senior author have studied the specimen as well as others given to us by fishermen from the village of Bay St. Lawrence, Cape Breton Island. Because we have been limited to specimens dragged off the sea floor (we have not seen them in situ and to date no money nor plans to do so exist) and by local fishing lore relating to their location plus a lack of data from industry and the government, this study has been limited. Oil companies and their contractors have concentrated their interests to the northwest and southwest in the Gulf of St. Lawrence towards the Magdalen Islands and Prince Edward Island where the potential for hydrocarbons is highest. Government interest has imitated the private sector interests, with some additional interest in the Dingwall - St Pauls Island - Newfoundland corridor where underwater cables are present. Essentially, with no recorded economic interest in the region of their occurrence other than fishing, little information is on record.

\section{DESCRIPTION}

\section{Location}

The material has been recovered from about $5 \mathrm{~km}$ offshore northwest of Cape St. Lawrence, Cape Breton Island, around co-ordinates $60.68^{\circ} \mathrm{W}$ longitude and $47.11^{\circ} \mathrm{N}$ latitude at 115 to 95 fathoms $(210-160 \mathrm{~m})$ water depth (Fig. 1). This area is on the upper reaches of the northwest-trending Laurentian Channel (Cabot Strait) of the Gulf of St. Lawrence where it intersects the northeast-trending Cape Breton Channel (or Trough). On the bathymetric and topographic coastal series maps, this area is on the southeast-facing slope edge of a large

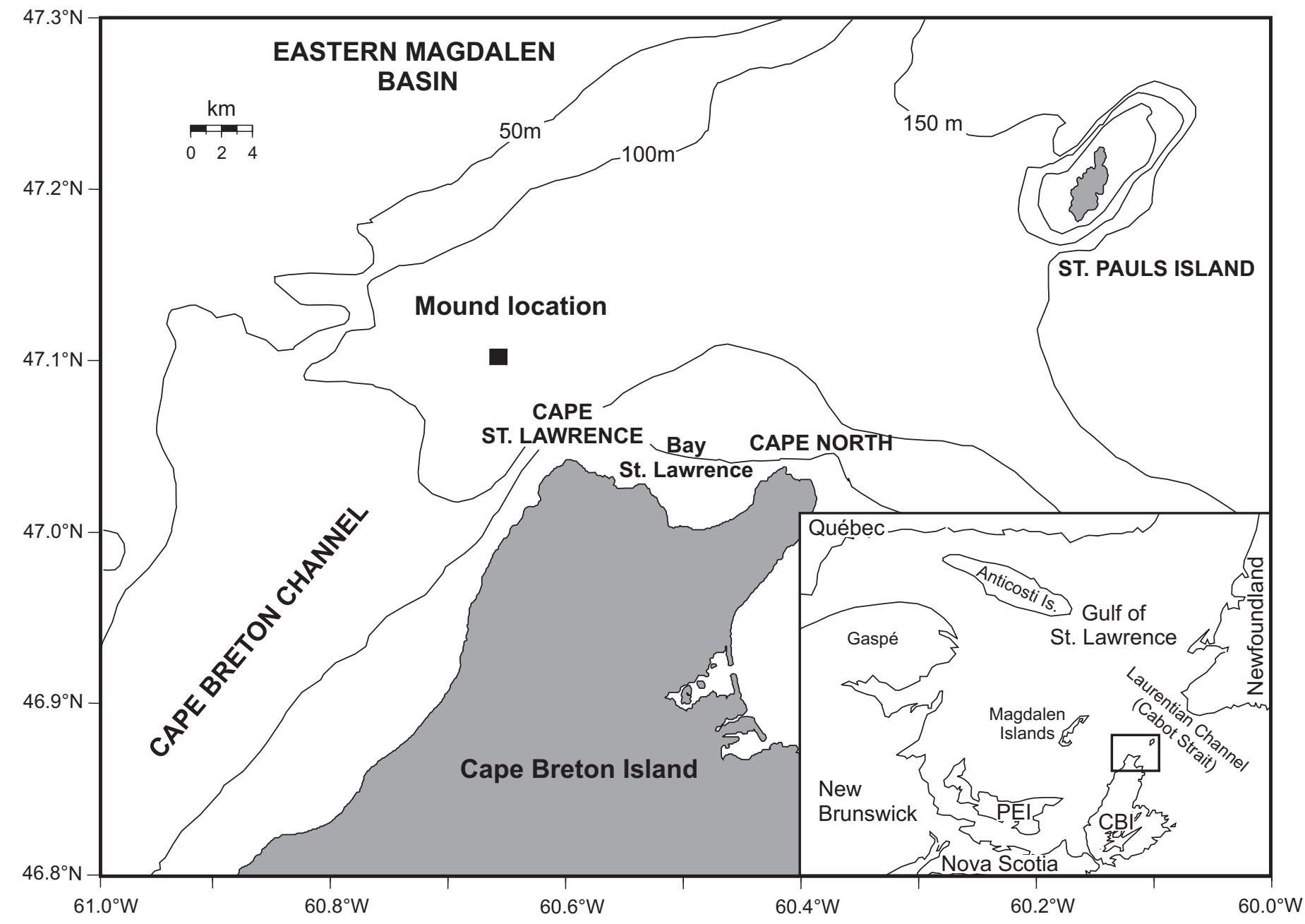

Fig. 1 Location Map. The box within the small regional map is the area of this study. 
basin in the area between St. Pauls Island, Cape St. Lawrence, and the northwest. Local fishing lore has the actual area being in a smaller basin-like depression ( 1 to $5 \mathrm{~km}^{2}$ area) with some fairly steep sides.

\section{Description of material}

According to the oral reports, the specimens range in size from several cubic decimeters to at least a cubic meter or more. A few of the smaller specimens have been retained by the fishermen as keepsakes (Fig. 2a) of which 6 were analysed by Harrington (2003) and others by Cook (2006). They are caught only in nets. In the year 2002 one fisherman recollects "catching" about 21 specimens over the short (few months) fishing season, indicating that they are quite common in the area. All specimens examined were obviously broken from larger pieces and or had pieces broken off.

Harrington (2003) classified the specimens into 3 broad categories on the basis of their physical characteristics: popcorn, layered, and eroded (Fig. 2). Further study of many more specimens brought to the university as well as viewed in the "fence" supports this classification (Fig. 2a). All three varieties exhibit interiors of micrite-cemented, fine- to coarse-grained sand and granule siliciclastic material and matrix, have included bioclasts, and are bio- and ?chemically eroded. Harrington (2003) showed the carbonate content of the specimens to range from $33 \%$ to $62 \%$. Microprobe analysis of the carbonate (cement and spar) shows low levels of $\mathrm{Fe}$ and $\mathrm{Sr}$ and the $\mathrm{Mg} / \mathrm{Ca}$ ratios are $<5 \%$. The carbon isotopic composition of calcite (analysis done at Saint Francis Xavier University using a "combustion" method) from 5 pelecypod shells and one brachiopod shell (a rhynchonellid) yielded $\delta^{13} \mathrm{C}$ values from -9.41 to $-35.27 \% 0$ $\mathrm{PDB}$ whereas an algae encrustation or bacterial mat yielded $-61.38 \%$ PDB. Some of the bio-eroded pores are infilled and/ or coated by sparry calcite. Bioclasts occur attached to the surface of the blocks as well as within the interior; no zonation of skeletons is apparent. The skeletons of invertebrates include pelecypods such as small juvenile oysters and many other species of clams, gastropods, and brachiopods (rhynchonellids), echinoid spines and parts of brittle starfish, foraminifera, and thin elongate skeletal tubes of calcite (several centimetres long by only a couple of millimetres diameter) that may be from an unidentified tube worm. Attached to the surface are coiled serpulid worm skeletons, muddy or chitinous tube worm casts (Pogonophora) up to $5 \mathrm{~cm}$ long, brittle starfish, and benthic foraminifera. Shells of the Arctic Boring Clam were also found in some of the larger pores. Some areas of some specimens are encrusted with fine carbonate from either carbonate-secreting algae or bacterial mats. In cut sections these encrustations are mainly seen in or are restricted to the present-day outer surface or are encrusting large pores connected to the outside. Essentially the dominant texture is one of agglutinated clasts cemented by calcite and subsequently eroded.

The popcorn variety of structure (Figs. 2d, 2e) shows no or little layering and is covered by more than $60 \%$ popcorn-like and intertwining framework or dendritic branches - it is very "clinkery" or rough. The central portions are silt and mud to fine sand-sized siliciclastic clasts in a micrite cement and parts of the exterior are coarser grained sparry-cemented pebble to granule conglomerate with quartzite and other rock fragments. All the popcorn branches are micrite bearing and branch size varies from about 8 to $10 \mathrm{~mm}$-diameter elongate structures to 1 or $2 \mathrm{~mm}$-sized rounded bumps. The evidence of bio- and chemical erosion is minimal on these varieties, as is large included shelly debris.

The layered variety (Figs. 2b, 2f) is overall composed of finer grains and is characterized by $\mathrm{cm}$-scale layers defined in two ways: one is a grain size difference between layers ranging from clay-sized to silt-sized (with a minor amount of fine sand) and the other is a textural difference with alternating layers of "structureless" muddy material and popcorn structures. Some layers are up to $95 \%$ carbonate plus mud. Most surfaces on the layered specimens are smooth and rounded in appearance except where popcorn-like structures are part of the layering. These varieties have the greatest amount of large shelly debris associated with them. Three separate vent-like structures were recovered (Fig. 2g) and because of their composition and finegrained muddy texture they have been included with this variety. One of the vent-like structures contained a smaller curved vent-like structure within the larger one.

The eroded variety (Fig, 2c) is highly porous, such that most of its original structure is lost (remembering that all varieties show some degree of erosion). The pores are both bio-eroded spaces and dissolution channels. These mounds seem to have been originally either a popcorn type or a muddy type similar to a single layer within the layered type. They are the least abundant of the three varieties of specimens recovered.

\section{Bedrock and surficial geology}

The geology of the offshore Cape St. Lawrence area around the recovery location is poorly known. Most work has been done either to the north or southwest or to the east of the cape. The recent and Pleistocene geology was interpreted by Josenhans et al. (1990) from cores and acoustical soundings to be either recent spill-over sands of the Laurentian Channel (over bedrock as seen in seismic line 89008 of Fig. 5) or glacial marine sediments (Fig. 3). The glacial marine material is mainly laminated pebbly silty clay thinly draped over till and up to 30 $\mathrm{m}$ thick. In the iceberg-turbated postglacial sediments to the northeast of St. Pauls Island, Josenhans et al. (1990) reported pockmarks up to $6 \mathrm{~m}$ deep (area shown on Fig. 3 ) and to the northeast of the Magdalen Islands they reported on a deep "mudlump" [sic] suspected of being formed by gas migration from depth.

The most extensive study of the offshore bedrock geology in the Cape region has been published by Howie (1988) and Langdon and Hall (1994) (Fig. 4). The rocks involved are the Horton, Windsor, and Mabou groups lying on an unknown pre-Horton Group basement. To the west and north to north- 

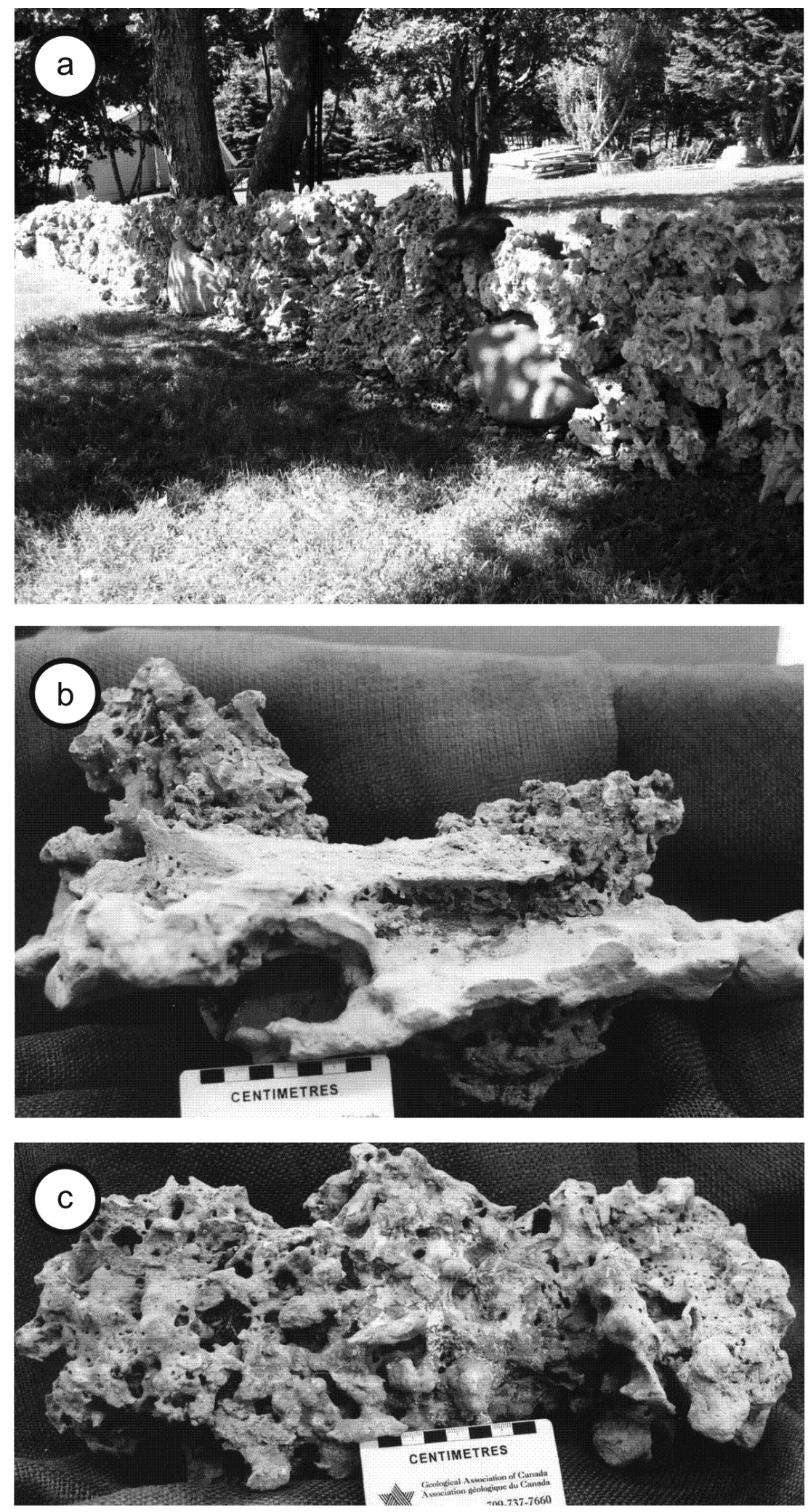
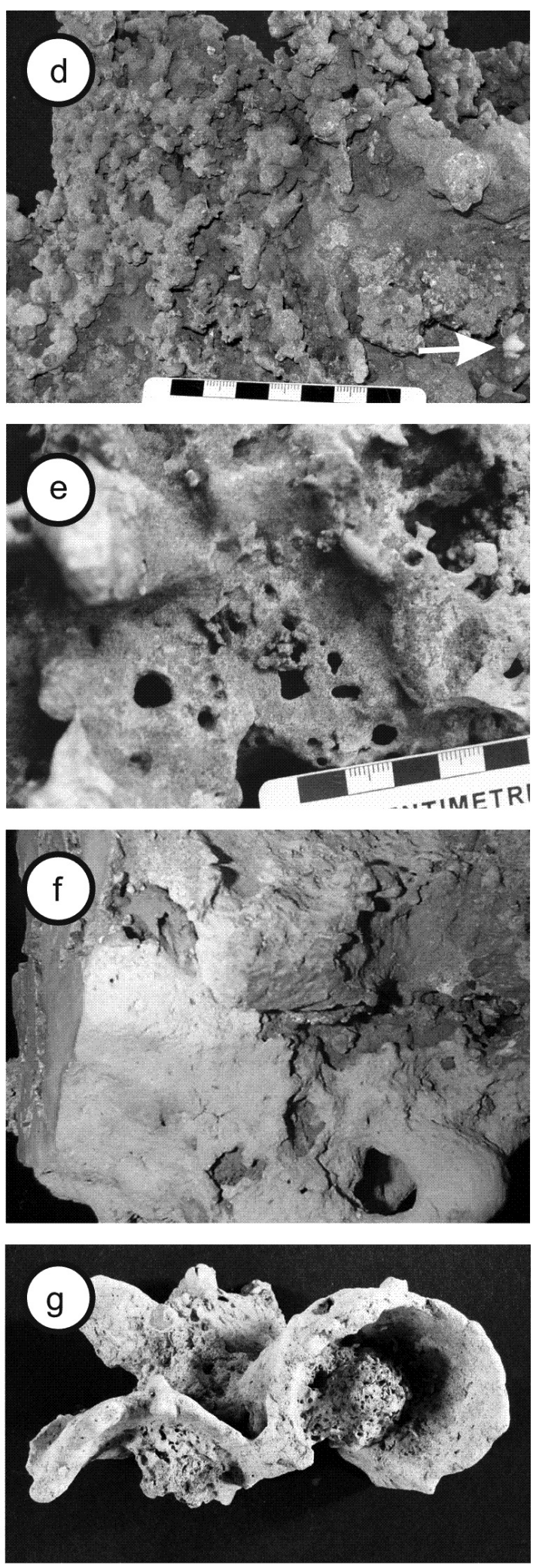

Fig. 2 Examples of recovered specimens. a) $30 \mathrm{~m}$ long "fence" comprised of more than 100 specimens, Bay St. Lawrence village, Cape Breton Island. b) Layered specimen where the layers are defined by alternating low porosity muddy carbonate and moderate porosity "popcorn" to dendritic carbonate. c) Highly porous and eroded specimen. d) Surface of "popcorn" and dendritic or clinkery specimen; note gastropod at lower right (arrow). e) Close-up of surface of clinkery carbonate showing porosity and surface structures. f) Close-up of low porosity muddy specimen, specimen $10 \mathrm{~cm}$ wide and cut on left surface. g) Vent structure, vent is $8 \mathrm{~cm}$ across. 


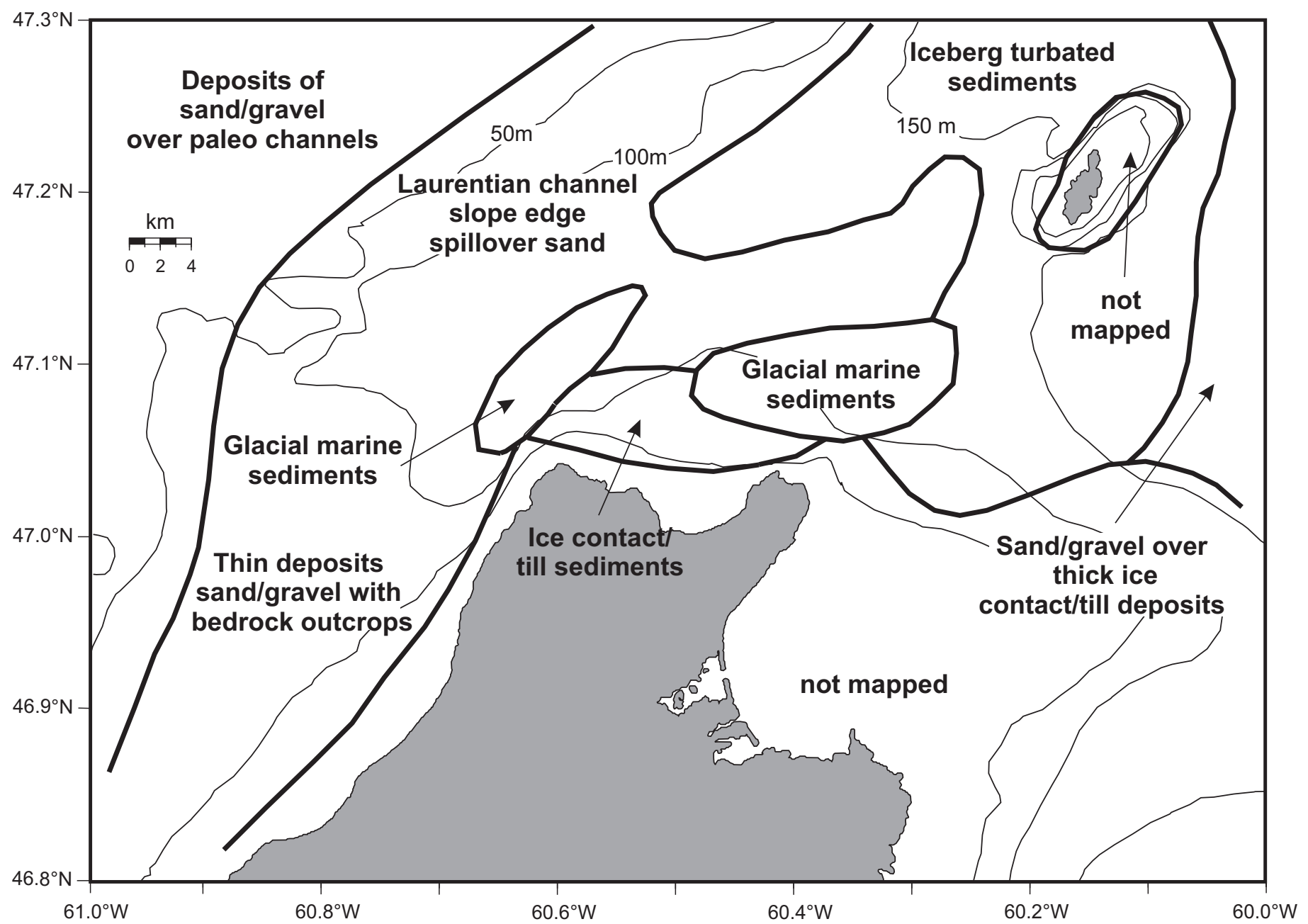

Fig. 3 Surficial geology map of region around the recovery area, modified from Josenhans et al. (1990).

east lies an area of extensive salt structures of Windsor age (Howie 1988; Durling and Marillier 1993) whereas to the immediate east and northeast, all three groups occur without salt tectonics, in a zone of detached faults between the northeaststriking Hollow Fault Zone and the Cabot Fault Zone (Aspy and Wilkie Brook Faults of Fig. 4). To the south and southeast onshore Cape Breton Island from Lowland Cove to the village of Bay St. Lawrence the rocks are lower to middle Horton Group coarse to fine siliciclastics (rudites to lutites) that have been extensively faulted and folded. Some of the rocks are black carbonaceous shales. In places in the village of Bay St. Lawrence, Windsor Group limestone has been faulted against clastic rocks of the Horton Group. Langdon and Hall (1994) interpreted the tectonic structure of the region to be a wrench system involving the major NE-trending faults with minor parallel and cross-cutting dextral fault arrays and shear zones (i.e., the St. Pauls Shear Zone). Extending these structures into the region of the recovery area indicates that the NE-trending (Hollow?) fault dips SE with a graben low to the south intersected by cross-cutting detachment faults or dextral shears. Howie (1988) and Durling and Marillier (1993) showed the Hollow Fault to be more steeply dipping, with the Cape Breton
Highlands horst coming up in the southeast and the Magdalen Basin going down. None of the sections are in the immediate area but what appears to be important is the change from a simple fault system west to northwest of Cape Breton Island to a complex wrench system in the Cabot Strait area.

\section{Hydrocarbon seeps}

Two areas of petroleum seeps or shows (detected as a strong smell to the rock, being most prominent when struck by a hammer) have been reported by Short (1986) for onshore Bay St. Lawrence and the fishermen in the region have reported on many more, of which only 3 are shown on Fig. 4 . The onshore seeps are mostly associated with faults juxtaposing Windsor Group limestone, conglomerate, and red shale against deep black shale of the Horton Group. In the areas of the seeps, bedding in the two rock groups is parallel, and the groups are juxtaposed by near-vertical faults at high angles to bedding. The faults are zones several meters wide of crushed and comminuted rock. Associated with these larger fault zones are minor narrower bedding-parallel faults, many of which are older than the across-bedding faults. In one small quarry, a 


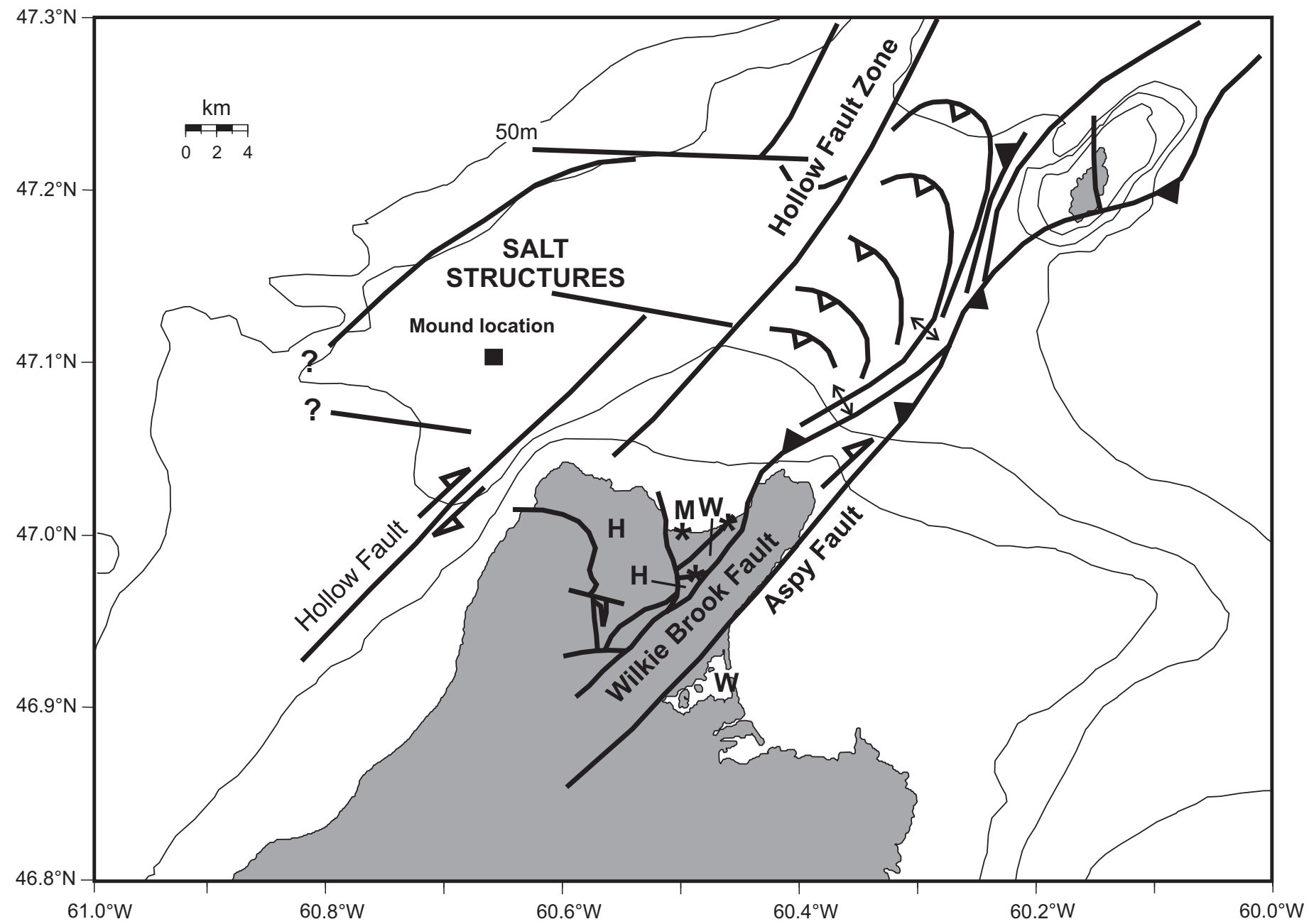

Fig. 4 Bedrock geology map of region around the recovery area. Offshore geology modified from Langdon and Hall (1994) and onshore geology modified from Keppie (2000). H = Horton Group, W = Windsor Group, M = Mabou Group, ${ }^{*}=$ onshore hydrocarbon seeps from Short (1986) plus field work; open hachured faults = detachments, closed hachured faults = down side

seep is associated with faulted black shale and sandstone of presumably Horton Group only, i.e., no limestone is present. Where the two groups outcrop together, petroleum is mainly associated with the relatively more permeable Horton Group to within about $15 \mathrm{~m}$ of the fault zone and only a minor amount in the Windsor Group.

\section{Seismic data}

Parts of publicly available seismic lines are relevant to this study (Fig. 5). One line (90028) runs NE - SW past the region and the other two cross this line north (95006) and south (89008) of the recovery area. On line 90028 the definition of features disappears into acoustic turbidity on the Huntec signal (as defined by Hovland and Judd 1988; Figs. 6a, 6b) about $6 \mathrm{~km} \mathrm{NE}$ of the vicinity of the recovery area to about $10 \mathrm{~km}$ southwest of the area. The sleevegun signal on this same line is not lost but definition of features is poor. On line 89008 most of the signal on both Huntec and airgun are lost to acoustical turbidity to within $4 \mathrm{~km}$ or more of the recovery area with only a few glimpses of bedrock structures to the west that appear to be associated with basement highs. Line 95006 has good definition of bedrock structures or highs with intervening thin sedimentary deposits to the northwest which gives way to acoustical turbidity to the southeast. Interestingly this zone of acoustical turbidity almost mimics the glacial-marine surficial sediment area of Fig. 3, other than being slightly displaced to the southeast and covering a larger area. These seismic lines also show three other types of interesting acoustical features before the signals are lost to turbidity. First, several "bright spots" (after Josenhans et al. 1990) are seen near the surface but also at depth (Fig. 6c). Second, a deep columnar sediment disturbance feature (Fig. 6d) is visible that at shallow depth looks similar to a bright spot but at depth is associated with a steep bedrock feature - interpreted to be most likely a bedrock fault. Third, some layers contain "diapir-like" structures (Fig. 6e), similar to the hydrate diapirs seen elsewhere (Hovland and Judd 1988), some of which are quite large. They are problematic to interpret but their association with the columnar disturbance seen in Fig. 6d, and their occurrence in sediment layers correlative 


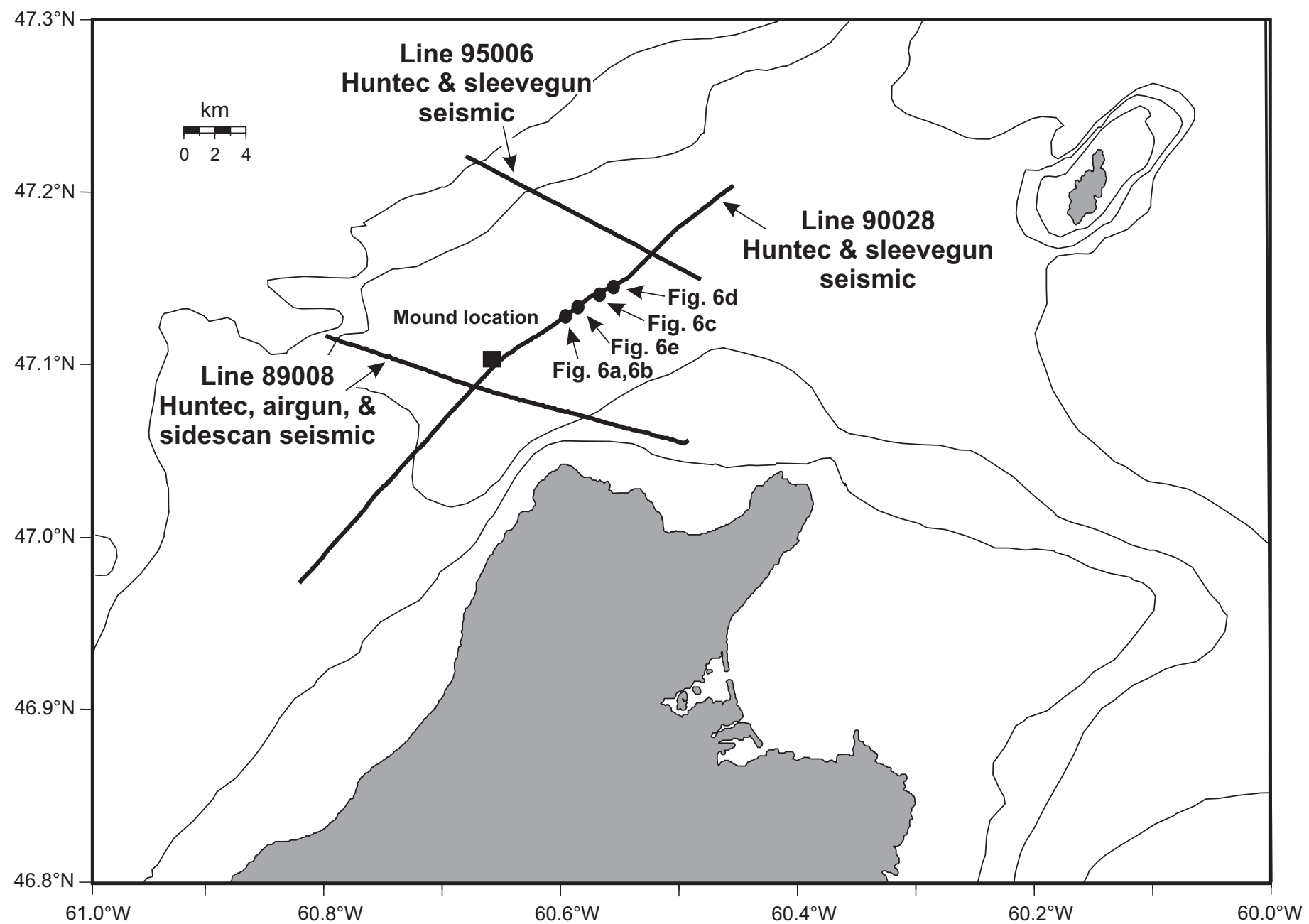

Fig. 5 Seismic lines that are of interest in the recovery area with the type of instrument for each line indicated and locations on line 90028 of images in Fig. 6.

with bright spots, leads us to believe that they too are features associated with hydrocarbons. On the sediment surface in the southeast part of line 95006, what appear to be pockmarks similar to those shown by Josenhans et al. (1990) section 12 are visible, but poorly defined. Definition of sedimentary layers starts to appear where these features are seen.

\section{DISCUSSION}

Comparing the texture, composition, and forms of the recovered specimens with mounds found by Grant et al. (1986) off Baffin Island at 360 to $430 \mathrm{~m}$ depths, Hovland and Judd (1988) in the North Sea, and Roberts et al. (1993) in the Gulf of Mexico leads us to believe that these specimens are parts of small carbonate mounds and hard surfaces. The included invertebrate fauna are from modern communities, eliminating their origin being from the indigenous Windsor Group and as well as eliminating the possibility that they are eroded modern concrete structures dropped off passing ships. Because these structures are only found in this small area by drag fishing and the draggers do not report getting caught on any larger structures on the sea bottom, the pieces recovered mostly likely are representative of their original size and composition, i.e. most specimens are probably in the order of 1 to several $\mathrm{m}^{3}$ and the 15 or so specimens examined in detail and the many more in the "fence" are most likely representative.

How and why these mounds formed is a more complicated story in that no specimens have been examined in situ, the region has not been explored extensively by seismic methods, and bathymetric data are scant. The presence of hydrocarbon seeps onshore associated with sedimentary rocks of the Horton and Windsor groups and the existence of these rocks and associated faults in the offshore area, as well as the active exploration for hydrocarbons immediately to the west, give credence to the possible existence of hydrocarbon in the sediments in this area. Acoustic turbidity occurs with about $7 \%$ hydrocarbon content in sediment (Hovland and Judd 1988) and bright spots are interpreted to result from the slowing down of the seismic signal by small pockets of gas in sediment. The 

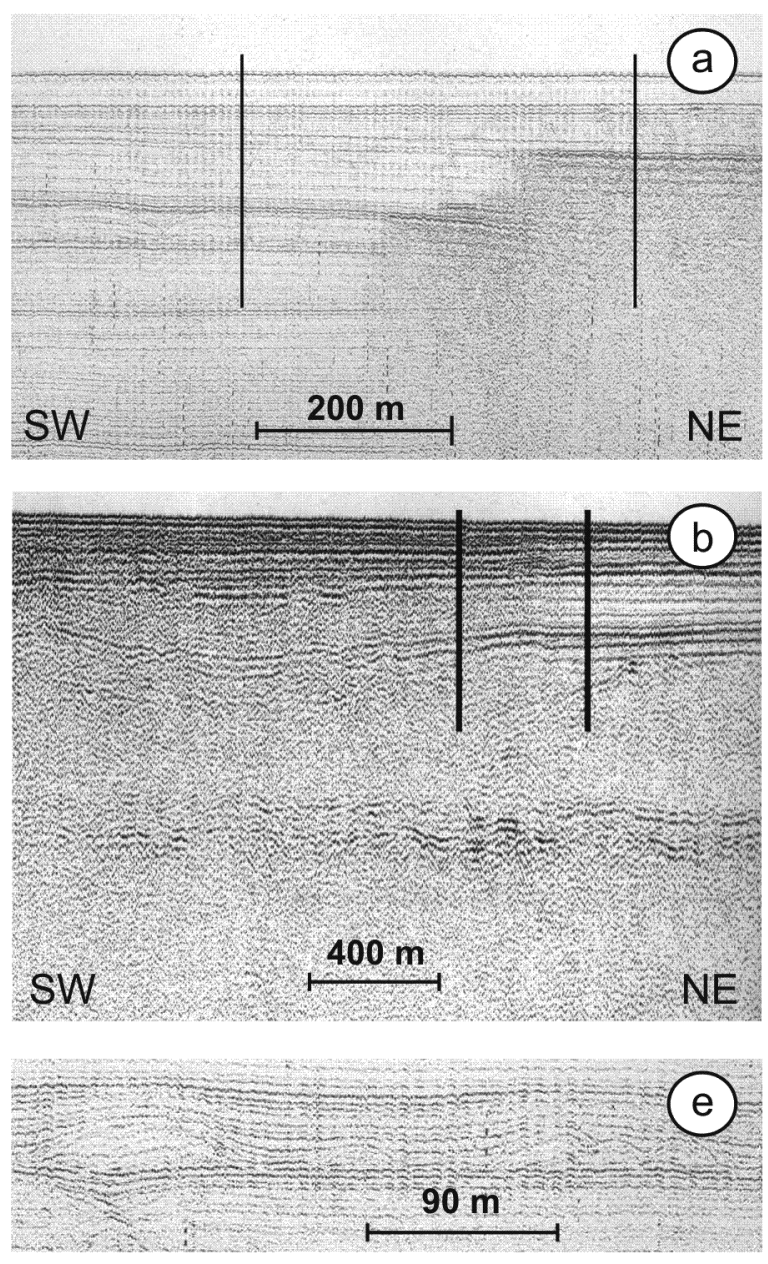
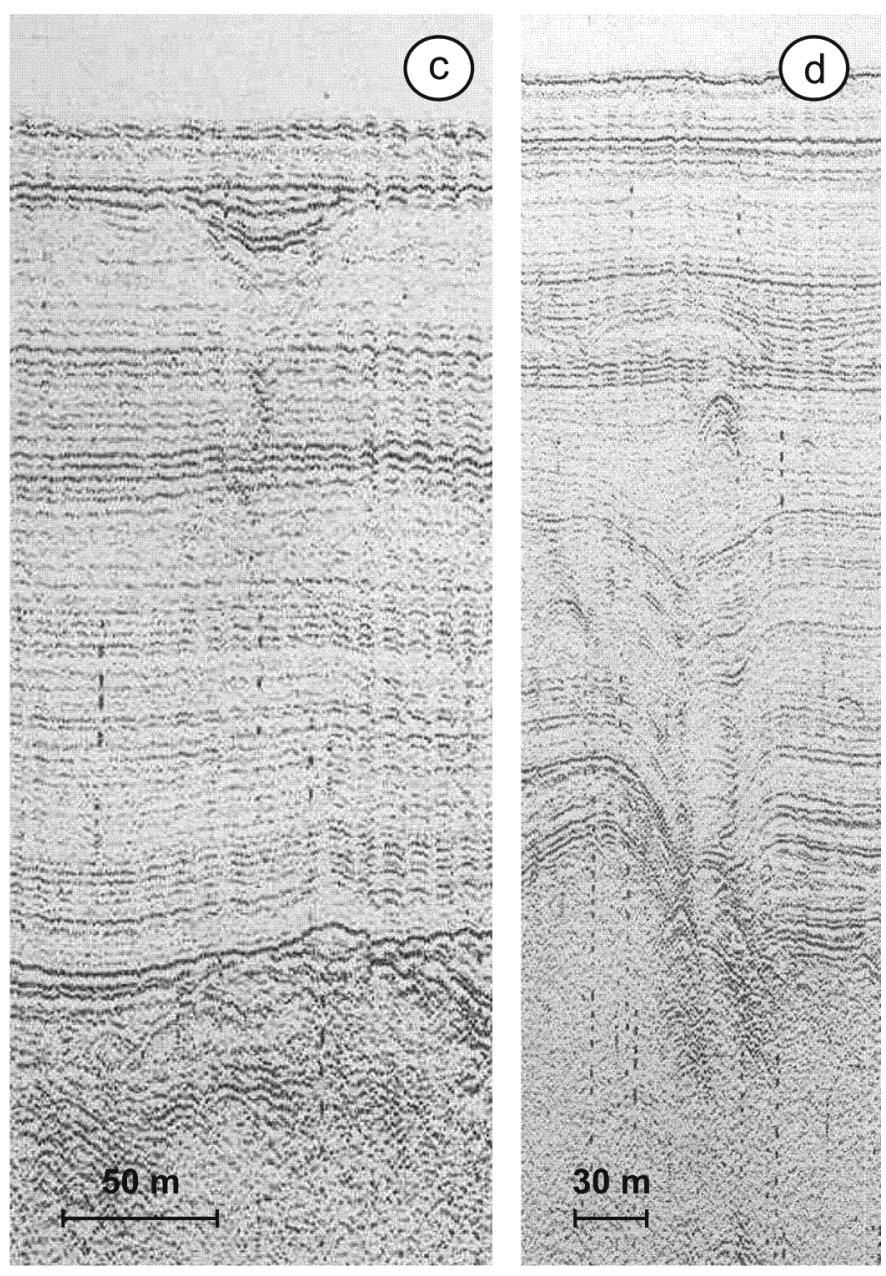

Fig. 6 Seismic structures seen along line 90028 and located on Fig.5. a) Well-defined layering in sediment record giving way to seismic turbidity, from Huntec record and b) from sleevegun record. Vertical lines on both images are the identical time markers. c) Bright spot. d) Columnar sediment disturbance arising from bedrock. e) Two adjacent seismic diapers-like structures. Note that towards the top of the columnar disturbance in d) there is a structure similar to the diaper-like structures. Structures d) and e) are on the same horizon and c) is on a younger horizon. Images c) - e) are from Huntec records.

seismic records indicate that the area of acoustical turbidity covers an area greater than that which contains the mounds but that the whole area is not much greater than a few tens of square kilometres. Thus the sediment most likely contains hydrocarbons around the recovery area. Outside the recovery area to the northwest and southwest and to the east the seismic signals are undisturbed, implying that the sediments there are hydrocarbon poor. The isotopic data cannot discriminate whether or not the carbon is recent (i.e. post-glaciation, $\sim 15$ -10 Ka ago) or ancient (i.e., from seeps associated with bedrock faults, from Carboniferous rocks). To compound the situation further, the seismic records indicate that both are possible as well. The columnar disturbance suggests that some, if not a major part, of the hydrocarbon may come from bedrock, most likely along faults. To the north bedrock faults are evident in the seismic record and fishing lore has the recovery area as a small, kilometre-scale basin with the southeastern edge a steep drop of several meters - interpreted to be a small fault scarp. The overwhelming evidence for hydrocarbon venting, however, is the presence of the recovered vent-like structures. Therefore these mounds are probably authigenic, forming today in the area where they are recovered and most likely associated with hydrocarbon seeps along faults.

Where there is hydrocarbon gas in the substrate, carbonate is probably produced by either methanogenesis of the hydrocarbon resulting in high concentrations of the $\mathrm{CO}_{3}^{-2}$ ion which in turn produces calcite or aragonite cement or through oxidation of the hydrocarbon directly to produce the cement. Carbon isotope values can indicate carbonate production by organisms from normal seawater or from seawater with reduced values of ${ }^{13} \mathrm{C}$ through methanogenesis or oxidation. Roberts (2000) showed for carbonates associated with seeps negative $\delta^{13} \mathrm{C}$ values in the range of -20 to $-50 \%$ PDB and little to no negative values for normal marine carbonates on the northern Gulf of Mexico Slope. Carpenter and Lohmann (1995) showed that modern brachiopod shells from the Bay of Fundy have little to no negative $\delta^{13} \mathrm{C}$ values, a finding similar to that of Roberts (2000). The shelly debris in these specimens 
came from sessile epi- and in-faunal organisms (mainly pelecypods and brachiopods but also encrusting algae or bacteria) that lived in the region and that are highly negative with respect to ${ }^{13} \mathrm{C}$. This high negativity most likely resulted from methanogenesis of hydrocarbon (carbon) originating in the sediment and subsequently into seawater where it was taken up by the organisms.

Hovland and Judd (1988, Figs. 8.3 and 9.3) give a model on the formation of small carbonate mounds associated with pock marks. Essentially the mound is an irregularly shaped object less than $1 \mathrm{~m}^{2}$ protruding out of the sediment. It has a foot composed of a crust of lithified material (zone I) surrounding an interior of highly porous unlithified material with some botryoidal aragonite (zone II). Penetrating into this interior as well as above is a third zone (III) of loosely to tightly cemented porous material with a myriad of connected voids, many lined with carbonate or filled with sand. The whole structure is capped by zone IV which is similar to zone III but highly pitted and corroded with very large voids. They interpreted these mounds to have formed by an upward flux of hydrocarbon-charged pore water reacting with oxygen-rich seawater near the sedimentseawater interface, causing precipitation of carbonate. A rich and concentrated fauna is associated with these features but they were not able to quantify this observation.

This model of formation can be modified to account for some of the varieties of structures recovered off Cape Breton Island in that they probably arose as a result of the interaction between the sediment and hydrocarbon flux from the sediment and bedrock. The dendritic or popcorn specimens probably grew where the flux was high, such that mixing of the sediment layers occurred during outgassing and some of the mud may have become entrained with the fluids and subsequently carried away, leaving the coarser portion behind. The dendritic pattern may also represent the myriad of hydrocarbon pathways in the subsurface. Parts of these specimens may have also been formed above the sediment surface through upwelling. These dendritic specimens are analogous to zone III of Hovland and Judd (1988). With the high hydrocarbon flux, bacterial activity may have been greater, resulting in more macro-fauna (sessile shelly organisms) and thus in their shells becoming part of the mound upon death (or even during life). Alternatively a slight depression in the sediment surface (incipient pock mark?) may have resulted in a lag deposit in the bottom that became encased in the mound during build-up.

The vents in the layered variety of structure could represent a higher hydrocarbon flux rate or, more likely, parts of the mound with longer lasting channels for the flow. They were definitely above the sediment surface, and again analogous to zone III. Vents within vents, vents that are curved, and muddy layers alternating with popcorn layers all point to the fact that the hydrocarbon flux rate is not constant over time and that the upright position of the mounds is potentially unstable. The bio- and chemically-eroded mounds with multiple holes and passageways are probably mounds that stopped their growth due to shutting off of the flux, equivalent to zone IV.

If the hydrocarbon gas production is low such that there is little to no disturbance of the substrate, the calcite may cement as a hard layer preserving the original bedding such as that seen in the second type of specimen of Harrington (2003). In this sense they are not parts of mounds as such and have no analogy to the zones of Hovland and Judd (1988). Alternatively they might be analogous to zone I in that they form sub-surface but most likely their formation would be similar to the formation of carbonate hard surfaces such as described by Malone et al. (2002) off New Jersey.

The recovered pieces are all well cemented specimens because they are dragged from depth while fishing and any weakly cemented or small protuberances would have been broken off or washed away, thus explaining why we do not see zones I and II.

Hovland and Judd (1988), Roberts (2000), Roberts et al. (1993), and others reported that carbonate deposits related to seeps usually occur when the hydrocarbon flux rate is low and in many cases they are found only associated with pockmarks. Pockmarks, in turn, are usually associated with areas where the acoustical turbidity is low. In the study area the acoustical turbidity is high and only outside the area where the carbonates are not found do we see pockmarks in the seismic record. This apparent contradiction is worth further study.

The fauna debris associated with the specimens is interesting. Long lining and drag fishing for the fish species sole started in the 1960s off Cape St. Lawrence, the only local area where that species is found. Currently, no other fish is sought in the immediate area either. Drag fishing involves disturbing the seabed to a depth of at least a meter or more, and it is probably within that depth that these carbonate mounds are forming. Sulphur-reducing bacteria feeding off the hydrocarbons at seeps may be the base of an invertebrate food chain that ends in sole, or the fish may be there because of the sediment type, regardless of the seeps and mounds. Hovland and Judd (1988) noted increased biological activity in the areas of the mounds that they studied; they reported 38 species of invertebrates around one mound, although the data were not quantified. From an environmental standpoint it is important to better document the distribution of these mounds and hydrocarbon seeps and to study their impact on fish habitat. Bacterial activity related to these seeps may be involved in the food chain and also needs to be further studied.

The fishermen of the area brought our attention to these structures because they thought they might be corals and important to the ecology of the area. They are concerned for many reasons but generally they want to better understand the ecology so they can catch fish in a more ecological fashion but also so that the fishery does not get shut down. Closing ecologically unique areas to fishing has been proposed by Enachescu (2004), specifically for the Orphan Knoll, off Newfoundland. This possibility should encourage further research by fishery, wildlife, and oceanography officials into the study area with the idea in mind of visiting the site with cameras and samplers.

No other occurrences or published descriptions of carbonate mounds are known from this region of the Northwest Atlantic or Gulf of St. Lawrence, let alone offshore Nova Scotia. 
Enachescu (2004) reported more than 200 large mounds hundreds of meters wide and maybe hundreds of meters high in deep-water in the Orphan Basin, offshore Newfoundland in the NW Atlantic, that might be bioherms or modern coral colonies related to water bottom hydrothermal vents, but no samples or pictures have ever been obtained. His conclusions are from indirect evidence and seismic interpretation. Authigenic carbonate in sediment at depth has been reported on the offshore New Jersey shelf from ODP cores (Malone et al. 2002) and there are numerous papers on carbonate mounds and associated structures from the Gulf of Mexico and North Sea regions. Recently findings have been reported off the west coast of Canada (V. Barry, personal communication 2005). As far as we know, this paper is the first published report on authigenic carbonate mounds from the central western Atlantic region.

\section{CONCLUSIONS}

This study is the first record and description of probable authigenic carbonate mounds in shallow to moderate water depths in Atlantic Canada. On seismic records they are associated with sediments that display acoustical turbidity, bright spots, shallow diapir-like charcateristics, and columnar sediment disturbances that reach to bedrock features interpreted to be faults. From carbonate and isotope analysis we are confident that they are formed by methanogenesis of hydrocarbon originating from seeps originating from faulted bedrock of the Carboniferous Horton and Windsor Groups. The mounds record through the inclusion of shelly debris a diverse and abundant invertebrate community that may be unique. More work is needed to understand the geology of the area, as knowledge of the ecology of these mounds is limited.

These features were first noticed by fishermen, this showing the value of local lore to scientific discovery. Scientists should be alert for other reports of similar features in adjacent regions, as they may be more common than originally thought.

\section{ACKNOWLEDGMENTS}

The authors wish to thank the Ecology Action Centre for bringing these very interesting specimens to our attention and for the many good questions and comments during poster presentations at geoscientific meetings in the region. Financial help for some of the analysis came from the Department of Earth Sciences, Dalhousie University and the carbon and oxygen isotope analysis was done at the Environmental Sciences Research Centre (ESRC), Environmental Earth Sciences Laboratory (EESL), at St. Francis Xavier University. Comments by the reviewers D. Keighly and V. Kostylev greatly helped in the presentations of our ideas.

\section{REFERENCES}

Carpenter, S.J., \& Lohmann, K.C. $1995 \cdot{ }^{18} \mathrm{O}$ and ${ }^{13} \mathrm{C}$ Values of Modern Brachiopods. Geochimica Cosmochimica Acta, 59, pp. 3749-3764.

Соок, R.W. 2006. Authigenic Carbonate Mounds and Hydrocarbon Seeps of Offshore Cape Breton Island, Nova Scotia. Unpublished BSc Thesis, Dalhousie University, Department of Earth Sciences, $50 \mathrm{p}$.

Durling, P., \& MARILliER, F. 1993. Structural Elements of the Magdalen Basin, Gulf of St Lawrence, from Seismic reflection Data. In Current Research, Part D, Geological Survey of Canada, Paper 93-1D, pp. 147-154.

Enachescu, M. 2004. Conspicuous Deepwater Submarine Mounds in the Northeastern Orphan Basin and on the Orphan Knoll, offshore Newfoundland. The Leading Edge, 23(12), pp. 1290-1294. (viewed at: http:/ /www.esd.mun.ca/faculty/members/enachescu_m/2004_ mounds_The\%20Leading\%20Edge.pdf on July 19, 2006).

Grant, A.C. Levy, E.M., Lee, K., \& Moffat, J.D. 1986. Pisces IV research submersible finds oil on Baffin Shelf. In Current Research, Part A, Geological Survey of Canada, Paper 86-1A, pp. 65-69.

Harrington, M.D. 2003. A study of Marine Carbonate Mounds off Bay St. Lawrence, Cape Breton Island, Nova Scotia. Unpublished BSc Thesis, Dalhousie University, Department of Earth Sciences, $62 \mathrm{p}$.

Hovland, M., \& Judd A.G. 1988. Seabed Pockmarks and Seepages: Impact on geology. Biology and the Marine Environment. Graham \& Trotman, London, UK, 293 p.

Howie, R.D. 1988. Upper Paleozoic Evaporites of Southeastern Canada, Geological Survey of Canada Bulletin 380, $120 \mathrm{p}$.

Josenhans, H., Zevenhuizen, J., \& MacLean, B. 1990. Preliminary seismostratigraphic interpretations from the Gulf of St. Lawrence. In Current Research, Part B, Geological Survey of Canada, Paper 90-1B, pp. 59-75.

Keppie, J.D. 2000. Geological Map of the Province of Nova Scotia. Nova Scotia Department of Natural Resources, Minerals and Energy Branch, Map ME 2000-1, scale 1:500 000 .

KInG, L.H., \& MacLean, B. 1970. Pockmarks on the Scotian Shelf. Geological Society of America, Bulletin, 81, pp. 314-3148.

Langdon, G.S., \& Hall, J. 1994. Devonian-Carboniferous tectonics and Basin Deformation in the Cabot Strait Area, Eastern Canada. American Association of Petroleum Geologists Bulletin, 78, pp. 1748-1774.

Malone, M.J., Claypool, G., Martin, J.B., \& Dickens, G.R. 2002. Variable Methane Fluxes in Shallow Marine Systems Over Geologic Time: The Composition and Origin 
of Pore Waters ad Authigenic Carbonates on the New Jersey Shelf. Marine Geology, 189, pp. 176-196.

Roberts, H.H. 2000. Fluid and Gas Expulsion on the Northern Gulf of Mexico Slope: Effects of Frequency and Magnitude on Seafloor Impacts with Special Emphasis on Gas Hydrates, American Association of Petroleum Geologists Annual Convention, April 16-19, New Orleans, LA., poster.
Roberts, H.H., Aharon, P., \& Walsh, M.M. 1993. ColdSeep Carbonates of the Louisiana Continental Slope-toBasin Floor. In Carbonate Microfabrics. Edited by R. Rezak and D. Lavoi. Springer-Verlag, Berlin. p. 95-104.

Short, G. 1986. Surface Petroleum Shows: Onshore Nova Scotia, Nova Scotia Department of Mines and Energy, Information Series No. 11, pp. 25.

Editorial responsibility: Donald L. Fox 
